\title{
The Effect Of Implementation Of Accrual-Based Government Accounting Standards On The Quality Of Local Government Financial Reports
}

Azwar Rivai Nasution

Department of Accounting, Univesity Of North Sumatra, Indonesia

\begin{tabular}{|c|c|}
\hline ARTICLE INFO & ABSTRACT \\
\hline Article history: & \multirow{4}{*}{$\begin{array}{l}\text { The aim of this research is to examine the effect of the application of } \\
\text { government accounting standard accrual to quality of financial } \\
\text { statement local government in the department of empowerment } \\
\text { communities and village government at South Tapanuli Government. } \\
\text { The population of this research are employees in the department of } \\
\text { empowerment communities and village government. The total } \\
\text { number of samples of this research are } 35 \text { people, which their data } \\
\text { collection are taken using questionnaires. This research is tested } \\
\text { using by simple regression. Research shows that the application of } \\
\text { government accounting accrual standard has a positive and } \\
\text { significant effect on the quality of local government financial } \\
\text { statements. }\end{array}$} \\
\hline $\begin{array}{r}\text { Receiv Jul 15, } 2021 \\
\text { Revised Aug 28, } 2021 \\
\text { Accepted Aug 30, } 2021\end{array}$ & \\
\hline Keywords: & \\
\hline $\begin{array}{r}\text { Government Accounting Accrual } \\
\text { Standard; } \\
\text { Quality Of Financial Statement; } \\
\text { Local Government. }\end{array}$ & \\
\hline
\end{tabular}

This is an open access article under the CC BY-NC license.

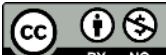

Corresponding Author:

Azwar Rivai Nasution, Department of Accounting, University Of North Sumatara, Indonesa,

Jl. Dr. Mansur No. 9 Padang Bulan, Kec. Medan Baru, Kota Medan 20222.

Email: azwarnasution@gmail.com

\section{INTRODUCTION}

In Indonesia, the comprehensive implementation of this accounting basis began in the 2015 fiscal year. To accommodate this application, in 2010 the Government issued Government Regulation Number 71 of 2010 concerning Government Accounting Standards (SAP) in lieu of Government Regulation (PP) of the Republic of Indonesia Number 24 of 2005 concerning Government Accounting Standards (SAP).

The most obvious change between the two regulations is the mandatory use of the accrual basis. In PP No. 24, the accounting basis used is the cash toward accrual basis or what is known as cash toward accruals. With the stipulation of PP No. 71 of 2010 then the application of the accrual-based government accounting system already has a legal basis. And this also means that the Government has an obligation to immediately implement the new SAP, namely the accrualbased SAP.

Changes in the accounting basis from cash to accruals to accruals have an impact on changes in the stages of recording and the types of financial statements produced. In addition, the application of an accrual-based accounting system in the government presents new challenges, therefore, in order for the implementation process to run properly, extra efforts are needed from the government in smoothing this transition process.

Government Accounting Standards (SAP) is a guideline in compiling and presenting financial reports in government, both central and local governments. With the existence of SAP, good governance will also be realized, which can carry out its administrative duties in accordance with 
the principles of good governance, including transparency, accountability, responsibility, openness, and fairness.

According to Nordiawan et al, (2007: 34) "To solve the various needs that arise in financial reporting, accounting and auditing in government, both the central government and local governments in the Republic of Indonesia, it is necessary to have a credible government accounting standard formed by a SAP committee" .

With the enactment of SAP, it is hoped that all accounting reports prepared by entities and government agencies in Indonesia, both central and regional, can follow the guidelines in this accounting standard so that financial reports can be of good quality because these Regional Government Financial Reports will later be used as a determining factor for financial policy. and decision-making tools by interested parties.

This thesis refers to previous research, the study said that there was a positive influence between Government Accounting Standards on the quality of financial reports by $82.1 \%$ (Arif, 2012). Meanwhile, the difference between this research and previous research lies in the object under study, changes in applicable legislation, different times and places.

Based on the above background, the researcher wishes to conduct a study with the title "The Effect of Accrual-Based Government Accounting Standards (SAP) in Local Governments on the Quality of Financial Reports at the Community Empowerment Agency and Village Government of South Tapanuli Regency, North Sumatra Province.

\section{RESEARCH METHOD}

This study uses a causal associative design. "Causal design is useful for measuring the relationships between research variables or useful for analyzing how a variable affects other variables" (Umar, 2003: 30). This study was conducted to determine and prove the relationship between Government Accounting Standards as an independent variable on the quality of financial statements as the dependent variable.

\subsection{Data Analysis}

\section{a. Validity Test}

Validity or validity is an index that shows the measuring instrument actually measures what is being measured. This validity concerns the accuracy of the instrument. To find out whether the prepared questionnaire is valid or valid, it is necessary to test the correlation between the score (value) of each question item and the total score of the questionnaire. The correlation technique commonly used is the product moment correlation technique and to find out whether the correlation value of each question is significant, it can be seen in the product moment value table or using SPSS to test it. Invalid question items must be discarded or not used as an instrument (Noor, 2011:132). The benchmark value for the validity test is the correlation coefficient which gets a value greater than 0.3 (Sekaran in Augustine and Kristaung, 2013:

\section{b. Reliability Test}

Reliability is a term used to indicate the extent to which a measurement result is relatively consistent if the measurement is repeated two or more times. Reliability is an index that shows the extent to which a measuring instrument can be trusted or reliable. Reliability testing is carried out on each construct or variable used in the study (Augustine and Kristaung, 2013:70). Reliability testing can be done using Cronbach's Alpha value (Augustine and Kristaung, 2013: 71-72). If Cronbach's Alpha value is greater than 0.6, then the research questionnaire is reliable (Augustine and Kristaung, 2013:73, Noor, 2011:165). Reliability testing must be carried out only on questions that already have or meet the validity test,

\section{c. Classic assumption test}

The classical assumption test is carried out before performing the regression analysis, so that it can be estimated that it is unbiased and efficient, the classical assumption test must be fulfilled including the tests of: (a) normality, and (b) heteroscedasticity. 


\section{d. Normality test}

Normality test aims to determine whether the distribution of a data follows or approaches the normal distribution. There are two ways to detect whether the data is normally distributed or not, namely the graph approach and the Kolmogrov-Smirnov approach.

\section{e. Heteroscedasticity Test}

Heteroscedasticity test aims to test whether in a regression model there is an inequality of variance from the residuals from one observation to another observation. If the variance of the residuals from one observation to another is constant, it is called Homoscedasticity. And if the variance is different, then it is called heteroscedasticity. A good regression model is that there is no heteroscedasticity. To detect the presence or absence of symptoms of heteroscedasticity is to look at the presence or absence of certain patterns on the scatterplot graph around the values of $X$ and $\mathrm{Y}$. If there is a certain pattern, then symptoms of heteroscedasticity have occurred.

\subsection{Hypothesis test}

The analytical method used to test the hypothesis in this study is simple regression analysis. Simple regression analysis is used to determine the direction of the relationship between the independent variable (Government Accounting Standards) and the dependent variable (Financial Report Quality) whether positive or negative and to predict the value of the dependent variable if the value of the independent variable increases or decreases. Data analysis was carried out using a computer program, namely SPSS (Statistical Package For Social Science).

\section{RESULTS AND DISCUSSIONS}

\subsection{Data analysis}

This study used a sample of 38 people, where the researcher distributed 38 questionnaires to respondents at the Community Empowerment and Village Government Agency (BPMPD) of South Tapanuli Regency located on Jalan Williem Iskandar, Padangsidimpuan City. However, only 35 questionnaires were returned, or in other words 35 respondents. So that all returned questionnaires will be sampled.

Table 1. Data Collection

\begin{tabular}{lcc}
\hline \multicolumn{1}{c}{ Information } & Amount & Percentage \\
\hline Questionnaire distributed & 38 & $100 \%$ \\
Questionnaire that does not return & 3 & $7.89 \%$ \\
Returning Questionnaire & 35 & $92.11 \%$ \\
Sample questionnaire & 35 & $92.11 \%$ \\
\hline
\end{tabular}

\section{a. Descriptive Analysis}

The instrument used in this study was a list of questionnaires. The total number of statements is twenty-three (23) statement items, namely eleven (10) statements for the variable Application of Accrual-Based Government Accounting Standards (X) and thirteen (13) statements for the variable Quality of Financial Statements $(\mathrm{Y})$.

Table 2. Frequency Distribution of Respondents' Answers

\begin{tabular}{cccccccccccccc}
\hline & P1 & P2 & P3 & P4 & P5 & P6 & P7 & P8 & P9 & P10 & P11 & P12 & P13 \\
\hline ST (1) & 0 & 0 & 0 & 0 & 0 & 0 & 0 & 0 & 0 & 0 & 0 & 0 & 0 \\
\hline TS (2) & 0 & 0 & 0 & 0 & 0 & 0 & 0 & 0 & 0 & 0 & 0 & 0 & 0 \\
KS (3) & 0 & 0 & 0 & 0 & 0 & 0 & 1 & 5 & 4 & 3 & 2 & 1 & 1 \\
S(4) & 32 & 30 & 33 & 28 & 30 & 27 & 31 & 27 & 30 & 30 & 30 & 32 & 33 \\
SS (5) & 3 & 5 & 2 & 7 & 5 & 8 & 3 & 3 & 1 & 2 & 3 & 2 & 1 \\
Total & 35 & 35 & 35 & 35 & 35 & 35 & 35 & 35 & 35 & 35 & 35 & 35 & 35 \\
\hline
\end{tabular}

Based on table 2 it can be seen that:

1) In item one statement of the questionnaire distributed and analyzed, it is known that there are 32 people $(91.4 \%)$ agree that financial statement information gives users the 
opportunity to evaluate the achievement of targets, then 3 people $(8.6 \%)$ strongly agree.

2) In the second statement item of the questionnaire distributed and analyzed, it is known that there are 30 people (85.7\%) agree that financial statement information helps users in predicting future financial performance, then 5 people (14.3\%) strongly agree.

3) In the third statement item of the questionnaire distributed and analyzed, it is known that there are 33 people $(94.28 \%)$ people agree that financial information is presented on time as needed in making decisions, then 2 people $(5.72 \%)$ strongly agree.

4) In the fourth statement item of the questionnaire distributed and analyzed, it is known that there are 28 people $(80 \%)$ agree that the financial statements in the LRA (Budget Realization Report) are presented in full, then 7 people (20\%) strongly agree.

Table 3. Frequency Distribution of Respondents' Answers

\begin{tabular}{ccccccccccc}
\hline & P1 & P2 & P3 & P4 & P5 & P6 & P7 & P8 & P9 & P10 \\
\hline ST (1) & 0 & 0 & 0 & 0 & 0 & 0 & 0 & 0 & 0 & 0 \\
TS (2) & 0 & 0 & 1 & 0 & 0 & 0 & 0 & 0 & 0 & 0 \\
KS (3) & 0 & 2 & 3 & 0 & 2 & 9 & 12 & 8 & 1 & 1 \\
S(4) & 24 & 18 & 21 & 17 & 29 & 20 & 18 & 25 & 33 & 32 \\
SS (5) & 11 & 15 & 10 & 18 & 4 & 6 & 5 & 2 & 1 & 2 \\
Total & 35 & 35 & 35 & 35 & 35 & 35 & 35 & 35 & 35 & 35 \\
\hline
\end{tabular}

1) In item one statement of the questionnaire distributed and analyzed, it is known that there are 24 people (68.57\%) agree that SAP 2010 is accrual-based to recognize income, expenses, assets, debt and equity in financial reporting then 11 people $(31.43 \%)$ are very agree.

2) In the second statement item of the questionnaire distributed and analyzed, it is known that 18 people $(51.43 \%)$ agree that they are able to provide information about the position and changes in the position of economic resources, liabilities and government equity then 15 people $(42.86 \%)$ strongly agree, and 2 people $(5.71 \%)$ disagree.

3) In the third statement item of the questionnaire distributed and analyzed, it is known that there are 21 people $(60 \%)$ agree that they are able to provide information about the source, allocation, and use of economic resources, then 10 people $(28.57 \%)$ strongly agree, 3 people ( $8.57 \%$ ) disagree, and 1 person (2.86\%) disagree.

4) In the fourth statement item of the questionnaire distributed and analyzed, it is known that there are 17 people $(48.57 \%)$ agree that they are able to provide information regarding compliance with the realization of their budget, then 18 people (51.43\%) strongly agree.

5) In the fifth statement item of the questionnaire distributed and analyzed, it is known that there are 29 people (82.86\%) agree that they are able to provide information about information and how the reporting entity funds its activities and fulfills its cash needs, then 4 people $(11.43 \%)$ strongly agree, and 2 people $(5.71 \%)$ disagree.

\subsection{Statistical Analysis}

\section{a. Validity and Reliability Test}

Validity or validity is an index that shows the measuring instrument actually measures what it measures. This validity concerns the accuracy of the instrument. To find out whether the prepared questionnaire is valid or valid, it is necessary to test the correlation between the score (value) of each question item and the total score of the questionnaire. The correlation technique commonly used is the product moment correlation technique and to find out whether the correlation value of each question is significant, it can be seen in the product moment value table or using SPSS to test it. Invalid question items must be discarded or not used as an instrument (Noor, 2011:132). The benchmark value for the validity test is the correlation coefficient which gets a value greater than 0.325 (Sekaran in Augustine and Kristaung, 2013:

After the data is obtained based on the distribution of questionnaires, then the data needs to be tested for validity and reliability tests. If the instrument or measuring instrument or questionnaire is not valid or reliable, then good research results will not be obtained (Noor, 2011:130, Zikmund, et al, 2009:309). the measurement is close to normal, then the number of respondents for the 
questionnaire trial should be at least 30 people. In this study, the questionnaire trial involved 35 respondents. The following are the results of the validity test on the questions from the variables of Financial Report Quality and Government Accounting Standards.

Table 4. Validity Test

\begin{tabular}{ccccc}
\hline No & Statement & rcount & rtable & Validity \\
\hline 1 & KLK1 & 0.466 & 0.325 & Valid \\
2 & KLK2 & 0.579 & 0.325 & Valid \\
3 & KLK3 & 0.553 & 0.325 & Valid \\
4 & KLK4 & 0.546 & 0.325 & Valid \\
5 & KLK5 & 0.482 & 0.325 & Valid \\
6 & KLK6 & 0.418 & 0.325 & Valid \\
7 & KLK7 & 0.655 & 0.325 & Valid \\
8 & KLK8 & 0.678 & 0.325 & Valid \\
9 & KLK9 & 0.715 & 0.325 & Valid \\
10 & KLK10 & 0.561 & 0.325 & Valid \\
11 & KLK11 & 0.723 & 0.325 & Valid \\
12 & KLK12 & 0.317 & 0.325 & Valid \\
13 & KLK13 & 0.565 & 0.325 & Valid \\
14 & SAP1 & 0.672 & 0.325 & Valid \\
15 & SAP2 & 0.663 & 0.325 & Valid \\
16 & SAP3 & 0.746 & 0.325 & Valid \\
17 & SAP4 & 0.621 & 0.325 & Valid \\
18 & SAP5 & 0.455 & 0.325 & Valid \\
19 & SAP6 & 0.774 & 0.325 & Valid \\
20 & SAP7 & 0.831 & 0.325 & Valid \\
21 & SAP8 & 0.792 & 0.325 & Valid \\
22 & SAP9 & 0.427 & 0.325 & Valid \\
23 & SAP10 & 0.525 & 0.325 & Valid \\
\hline
\end{tabular}

Source: SPSS Data Processing Results (May 2016)

Reliability test results based on data processed with the help of applications SPSS 17 Software for Windows can be seen in the following table:

Table 5. Reliability Test

\begin{tabular}{ccccc}
\hline Variable & Cronbach's Alpha & Critical Value & Information & Conclusion \\
\hline $\begin{array}{c}\text { Report Quality } \\
\text { Finance }\end{array}$ & 0.761 & 0.6 & $0.761>0.6$ & Reliable \\
$\begin{array}{c}\text { Standard } \\
\text { Government }\end{array}$ & 0.740 & 0.6 & $0.740>0.6$ & Reliable \\
Accounting & & & & \\
\hline
\end{tabular}

If Cronbach's Alpha value is greater than 0.6 then the research questionnaire is reliable (Augustine and Kristaung, 2013:73, Noor, 2011:165). It is known that Cronbach's Alpha value of the variables of Quality of Financial Statements and Government Accounting Standards is greater than 0.6 so it can be stated that the questionnaire is reliable and can be distributed to respondents to be used as research instruments.

\subsection{Classical Assumption Test}

\section{a. Normality Test}

The classical assumption test is carried out before performing the regression analysis, so that it can be estimated that it is unbiased and efficient, a classical assumption test is carried out that must be met, the first is the normality test. There are two ways to detect whether the data is normally distributed or not, namely the graph approach and the Kolmogrov-Smirnov approach.

\section{b. Heteroscedasticity Test}

This heteroscedasticity test aims to test whether in the regression model there is an inequality of variance from the residuals of one observation to another observation. If the residual variance from one observation to another observation remains, it is called homoscedasticity and if it is 
different it is called heteroscedasticity. A good regression model is one with homoscedasticity or no heteroscedasticity. The basis of the analysis is that there is no clear pattern, and the points spread above and below the number 0 on the $Y$ axis, then there is no heteroscedasticity, whereas if there is a certain pattern, such as dots that form a certain regular pattern, it indicates that there has been a heteroscedasticity.

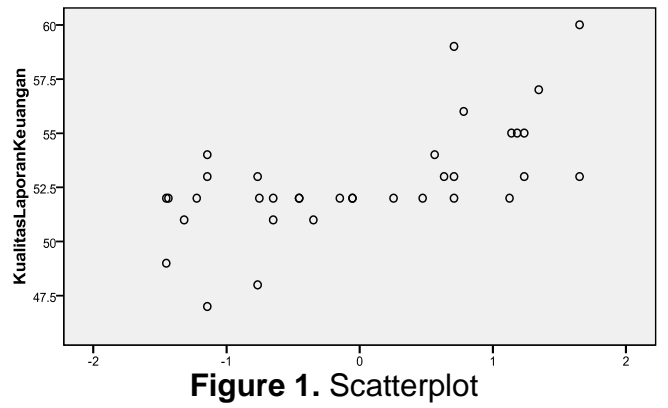

Based on Figure 1, it can be seen from the ScatterPlot graph presented, there is no clear pattern, and the points spread above and below the number 0 on the $Y$ axis, so there is no heteroscedasticity.

\subsection{Hypothesis Test}

The results of a simple linear regression to determine the effect of the application of government accounting standards on the quality of government financial statements are shown in Table 6 below:

Table 6. Simple Regression Analysis Test Results

\begin{tabular}{|c|c|c|c|c|c|c|}
\hline \multirow{2}{*}{\multicolumn{2}{|c|}{ Model }} & \multicolumn{2}{|c|}{ Unstandardized Coefficients } & \multirow{2}{*}{$\begin{array}{l}\text { Standardized } \\
\text { Coefficients } \\
\text { Beta }\end{array}$} & \multirow[t]{2}{*}{$\mathrm{t}$} & \multirow[t]{2}{*}{ Sig. } \\
\hline & & $B$ & Std. Error & & & \\
\hline 1 & $\begin{array}{c}\text { (Constant) } \\
\text { SAP }\end{array}$ & $\begin{array}{c}43,950 \\
.216 \\
\end{array}$ & $\begin{array}{c}5.191 \\
.126\end{array}$ & .285 & $\begin{array}{l}8,467 \\
1,711 \\
\end{array}$ & $\begin{array}{l}.000 \\
.097\end{array}$ \\
\hline
\end{tabular}

The regression equation can be seen from the table of Coefficients test results. In the coefficients table, the value in column B in the first row shows the constant (a) and the next row shows the constant of the independent variable.

\section{a. Partial Significance Test (t Test)}

The individual partial significance test is a test to test whether the value of the individual partial regression coefficient is zero or not (Gujarati, 2003:250, Supranto, 2005:196).

Table 7. Partial Test Results (T Test)

\begin{tabular}{|c|c|c|c|c|c|c|}
\hline \multirow{2}{*}{\multicolumn{2}{|c|}{ Model }} & \multicolumn{2}{|c|}{ Unstandardized Coefficients } & \multirow{2}{*}{$\begin{array}{l}\text { Standardized } \\
\text { Coefficients } \\
\text { Beta }\end{array}$} & \multirow[t]{2}{*}{$\mathrm{t}$} & \multirow[t]{2}{*}{ Sig. } \\
\hline & & B & Std. Error & & & \\
\hline 1 & $\begin{array}{c}\text { (Constant) } \\
\text { SAP }\end{array}$ & $\begin{array}{c}43,950 \\
.216 \\
\end{array}$ & $\begin{array}{l}5.191 \\
.126 \\
\end{array}$ & 285 & $\begin{array}{l}8,467 \\
1,711 \\
\end{array}$ & $\begin{array}{l}.000 \\
.097\end{array}$ \\
\hline
\end{tabular}

Based on Table 7 it can be seen that:

The t-count value of the variable Government Accounting Standards Application is 1.711 and the t-table value is 2.01 then tcount> ttable $(1.771>2.01)$ and significant value $(0.000<0.05)$ so that it can be concluded that partially the influence of the Accrual-Based Government Accounting Standards application variable has a positive and significant effect on Quality of Financial Reports. This means that if the variable of the Implementation of Government Accounting Standards is increased, the Quality of Financial Reports does not increase by 0.216 units. 


\section{b. Determinant Coefficient Test (R2)}

The coefficient of the determinant ranges from zero to one $(0 \leq R 21)$. If $R 2$ is getting bigger (closer to one), it can be said that the influence of the independent variable $(X)$ on the dependent variable $(y)$ is great. This means that the model used is getting stronger to explain the influence of the independent variable on the dependent variable and vice versa.

Table 8. Determinant Coefficient Test Results (R2) Model Summaryb

\begin{tabular}{ccccc}
\hline Model & $\mathrm{R}$ & $\mathrm{R}$ Square & Adjusted R Square & $\begin{array}{c}\text { Std. Error of the } \\
\text { Estimate }\end{array}$ \\
\hline 1 & $.632 \mathrm{a}$ & .399 & .149 & 2,377 \\
\hline Source: Data Processing Results (May 2016)
\end{tabular}

Based on Table 8 it can be seen that:

1) $R=0.632$ means that the relationship between the variables of the Implementation of Government Accounting Standards on the dependent variable of Financial Report Quality $(\mathrm{Y})$ is $63.2 \%$, which means that the relationship is very close.

2) R Square of 0.399 means that $39.9 \%$ of the variable Quality of Financial Statements can be explained by the variable Application of Government Accounting Standards. While the remaining $60.1 \%$ can be explained by other variables not examined in this study.

\section{CONCLUSION}

The application of Accrual-Based Government Accounting Standards has a positive and significant impact on the Quality of Local Government Financial Reports at the Community Empowerment Agency and Village Government of South Tapanuli Regency.

The higher the level of application of Accrual-Based Government Accounting Standards, the higher the quality of the financial statements of the Community Empowerment Agency and the Village Government of South Tapanuli Regency.

\section{REFERENCES}

Abdul Halim, 2007. Akuntansi Sektor Publik (Akuntansi Keuangan Daerah), Jakarta, Salemba Empat. Bastian, Indra. 2006. Akuntansi Sektor Publik, Erlangga, Jakarta.

Erlina, 2008. Akuntansi Sektor Publik: Akuntansi Untuk Satuan Kerja Perangkat Daerah, USU Press, Medan Forum Diskusi Akuntansi Sektor Publik, 2006. Standar Akuntansi Pemerintahan Telaah Kritis PP Nomor 24 Tahun 2005, BPFE, Yogyakarta.

Govermental Accounting Standard Board, 1998.Governmental Accounting and Financial Reporting Standards.GASB, Norwal, Conn.

Gujarati, D.N. 2003.Basic Econometrics 4th Edition. New York: Mc Graw Hill. Kusumah, Arif Ardi 2012. Pengaruh Penerapan Standar Akuntansi Pemerintahan Terhadap Kualitas Laporan Keuangan

Mahsun Mohammad, Firma Sulistyowati, dan Heribertus A.P, 2007. Akuntansi Sektor Publik Edisi Kedua, BPFE. Yogyakarta.

Muda, I., \& Rasdianto, M. S. L. (2014). Implementation of the Cash Revenue System: A Case Study in the Local Government Task Forces' Units of North Sumatera Province, Indonesia. Information Management \& Business Review, 6(2).

Nugraheni, Purwaniati dan Subaweh, Imam, 2008. Pengaruh Penerapan Standar Akuntansi Pemerintahan Terhadap Kualitas Laporan Keuangan. http://ejournal.gunadarma.ac.id/index.php/ekbis/article/view/321

Noor, J. 2011. Metodologi Penelitian untuk Skripsi, Tesis, Disertasi \& Karya Ilmiah. Jakarta: Kencana.

Nordiawan, Deddi, 2006. Akuntansi Sektor Publik, Salemba Empat, Jakarta.

Permadi, Angga Dwi 2013. Pengaruh Penerapan Sistem Akuntansi Keuangan Pemerintah Terhadap Kualitas Laporan Keuangan Pemerintah Daerah. http://ejournal.widyatama.ac.id/index.php/article/view/612

Peraturan Pemerintah Nomor . 24 Tahun 2005 Tentang Standar Akuntansi Pemerintahan. Jakarta.

Peraturan Pemerintah Nomor 58 Tahun 2005 Tentang Pengelolaan Keuangan Daerah. Jakarta.

Peraturan Pemerintah Nomor 71 Tahun 2010 Tentang Standar Akuntansi Pemerintahan. Jakarta.

Peraturan Pemerintah Nomor 105 tahun 2000 Tentang Pengelolaan dan Pertanggung jawaban Keuangan Daerah, Jakarta. 
Rasdianto,N, \& Muda, I. (2014). Analysis on the Timeliness of the Accountability Report by the Treasurer Spending in Task Force Units in Indonesia. International Journal of Academic Research in Accounting, Finance and Management Sciences, 4(4), 176-190.

Sekaran, U. 2003. Research Methods for Business $4^{\text {th }}$ Edition. New York: John Wiley \& Sons Inc.

Sinaga, Jamason, 2005. Selamat Datang Standar Akuntansi Pemerintahan.

Sujoko Efferin, Stevanus Hadi Darmadji, danYuliawati Tan, 2008. Metode Penelitian Akuntansi; Mengungkap Fenomena dengan Pendekatan Kuantitatif dan Kualitatif, Grahallmu, Yogyakarta.

Sugiyono, 2006. Metode Penelitian Bisnis, Cetakan kedelapan, CV Alfabet, Bandung.

Tanjung, Abdul Hafiz, 2008. Akuntansi Pemerintahan Daerah. Konsep dan Aplikasi, Cetakan Kedua, Alfabeta, Bandung.

Undang-Undang Nomor 1 Tahun 2004 Pasal 57 Tentang Perbendaharaan Negara. Jakarta.

Undang-Undang Nomor 17 Tahun 2003 Pasal 32 Tentang Keuangan Negara. Jakarta.

Undang-Undang No. 33 tahun 2004 Tentang Perimbangan antara Keuangan Pemerintah Pusat dan Pemerintah Daerah. 